the carapace and chelæ are smooth and not pitted. They are pitted in the British forms Xantho incisus Leach and $X$. pilipes Milne Edwards. In Xantho, moreover, the second lateral tooth on the carapace is relatively more distinct than in Neopanope and teeth 3 and 4 are not recurved forwards.

I am grateful to Dr. Isabella Gordon and Mr. R. Ingle for their help at the British Museum (Natural History). Mr. W. A. C. Morris kindly provided information about shipping which operates betwoen North America and Swansea.

Department of Zoology,

E. NAXLOR

University College of Swansea.

'Rathbun, M. J., Smithsonian Inst. U.S. Nat. Mus., Bull. 152 (Wash. ington, 1930).

2 Ryan, E. P., Amer. Midl. Nat., 56, 138 (1956).

Wolff, T., Nature, 174, 188 (1954).

4 Naylor, E., Proc. Fifteenth Int. Congr. Zool., 259 (1959).

${ }^{5}$ Naylor, E., Nature, 180, 616 (1957).

'Naylor, E., Ann. Mag. Nat. Hist., 12, 521 (1957).

'Drach, P., and Forest, J., Arch. Zool. Exp. Gén., 90, 1 (1953).

\section{Earthworm Population Studies : a Comparison of Sampling Methods}

SVENDSEN $^{1}$ showed that the estimate of an earthworm population obtained by hand sorting soil samples was much greater than that by the prevalent method of bringing worms to the soil surface with potassium permanganate solution, and so emphasized that, although laborious, hand sorting was more accurate for population studies. The accuracy of estimates by hand sorting has not been studied but is likely to depend on soil type and conditions, as well as on the time and care taken to examine the sample. One way to estimate accuracy is to see how many worms can be recovered when samples, already hand sorted, are examined again by a different method.

While investigating the role of earthworms when marginal land is reclaimed, their abundance had to be estimated in experimental plots on a hill farm in Lancashire where the soil is relatively shallow, has a poor, unstable structure, and is covered by a surface mat of vegetation. This mat and the underlying soil were usually wet and often waterlogged, and preliminary work showed that the earthworms were confined to the top few inches of the soil profile. Soil samples were taken for hand sorting, and, to estimate the proportion of the population counted in this way, 9 of the sorted samples, 3 from each of 3 experienced workers, were examined again in the following way.

The vegetation was separated from the mineral fraction by gently washing and shaking the sample in a $2-\mathrm{mm}$. sieve suspended within a $0 \cdot 5-\mathrm{mm}$. sieve standing in a bowl of water. Worms were then collected from the vegetation by teasing it in another bowl of water containing a few c.c. of formalin to make the worms wriggle and so be more obvious. After the mineral fraction was washed through the 2 -mm. sieve into the $0 \cdot 5-\mathrm{mm}$. sieve, so freeing any worms from soil crumbs, this sieve was shaken in the water for a time to allow silt to pass through it. It was then immersed in magnesium sulphate solution, of density 1-2, when the worms floated and were collected.

Table 1 shows that hand sorting recovered 52 per cent of all the worms found in the samples. This corresponded to 84 per cent of the weight, which shows that hand sorting mainly misses the smaller
Table 1. RECOVERY OF EARTHWORMS FROM NINE SOM SAMPLES BY HAND SORTING AND WASHING

\begin{tabular}{|c|c|c|c|c|c|}
\hline & & $\begin{array}{l}\text { Worms } \\
\text { found } \\
\text { by hand } \\
\text { sorting }\end{array}$ & $\begin{array}{l}\text { Additional } \\
\text { worms } \\
\text { found by } \\
\text { washing }\end{array}$ & $\begin{array}{l}\text { TotaI } \\
\text { found }\end{array}$ & $\begin{array}{c}\text { Percentage } \\
\text { found } \\
\text { by hand } \\
\text { sorting }\end{array}$ \\
\hline \multirow{2}{*}{$\begin{array}{l}\text { All } \\
\text { species }\end{array}$} & \multirow{2}{*}{$\begin{array}{l}\text { Number } \\
\text { Weight } \\
\text { (gm.) }\end{array}$} & 256 & 236 & 492 & 52 \\
\hline & & $13 \cdot 47$ & $2 \cdot 55$ & $16 \cdot 02$ & 84 \\
\hline \multirow{2}{*}{$\begin{array}{c}\text { Eiseniella } \\
\text { tetraedra }\end{array}$} & \multirow{2}{*}{$\begin{array}{l}\text { Number } \\
\text { Weight } \\
\text { (gm.) }\end{array}$} & 125 & 208 & 333 & 38 \\
\hline & & $2 \cdot 38$ & $1 \cdot 81$ & $4 \cdot 19$ & 57 \\
\hline
\end{tabular}

worms. How this selective loss can affect population estimates is well shown by the results for a small species such as Eiseniella tetraedra. Hand sorting recovered only 38 per cent of the total number and 57 per cent of the total weight of this species found in the samples and suggested that it comprised 49 per cent of the total number and 18 per cent of the total weight of all species. When the worms recovered by washing are included, E. tetraedra comprised 68 per cent of the total number and 26 per cent of the total weight of the population. Clearly hand soiting was unsatisfactory for this habitat, and the washing method, though no more laborious, was preferable.

In similar tests with soil samples from grassland with no surface mat on a light, well-drained soil at Wisbech, and from a heavier, well-drained soil at Rothamsted, 89 per cent of the total number and 95 per cent of the total weight found was recovered by hand sorting, which was also much quicker than washing. In contrast, hand sorting samples from an old arable field with heavy soil and poor structure recovered only 59 per cent of the total number and 90 per cent of the total weight found and was no quicker than washing.

The washing method not only provides a check on the efficiency of hand sorting, but, for some habitats, also provides a much more accurate estimate of the earthworm population. The washing method has the further advantage that it can be adapted to extract earthworm egg capsules and so estimate all stages of the population.

Entomology Department,

F. RAW

Rothamsted Experimental Station, Harpenden, Herts.

Jan. 27.

${ }^{1}$ Svendsen, J. A., Nature, 175, 864 (1955).

\section{Modification of the Neurocranium in Zygaena malleus and the Nature of the Optic Stalk in Selachii}

Generaliy in Selachii, between the nasal and auditory capsules, on each side, are the orbits in which the eyes are lodged. The orbit is overhung by the supraorbital cartilage which extends anteriorly and posteriorly to the orbit as the pre- and postorbital processes respectively. The optic capsule, which is represented by the sclerotic cartilage, does not fuse with the brain-case, as the nasal and auditory capsules do ; but it is held away from the orbital wall by the cartilaginous optic stalk, which is proximally fused with the orbital wall.

In Zygaena malleus only the most anterior and most posterior parts of the supraorbital cartilage are represented, forming the pre- and post-orbital processes. The orbit (Fig. 1, Or.) has retained a secondary 